\title{
THE CHARACTERISTICS OF FRUITS MORPHOLOGY, CHEMICAL COMPOSITION AND COLOUR CHANGES IN MUST DURING MACERATION OF THREE GRAPEVINE CULTIVARS
}

\author{
Ireneusz OCHMIAN ${ }^{1 *}$, Ludmil ANGELOV ${ }^{2}$, Piotr CHEŁPIŃSKI ${ }^{1}$, Bojan STALEV ${ }^{2}$, \\ Rafał ROZWARSKI ${ }^{1}$, Agnieszka DOBROWOLSKA ${ }^{1}$ \\ ${ }^{1}$ Department of Horticulture, West Pomeranian University of Technology in Szczecin \\ Słowackiego 17 str., 71-434 Szczecin, Poland \\ ${ }^{2}$ Department of Viticulture, Agricultural University in Plovdiv, \\ Mendeleev 12 str., 4000 Plovdiv, Bulgaria; e-mail: vitis.vin_29@abv.bg \\ Received: December 14, 2012; Accepted: June 27, 2013
}

\begin{abstract}
The study compares morphology of clusters and fruits, the chemical composition and changes of pulp in the process of maceration of grape cultivars 'Mavrud', 'Pinot Noir' and 'Merlot'. The cultivar 'Mavrud' had biggest clusters and fruits. Its fruits were less firm but had the highest acidity while the fruits of the 'Pinot Noir' had the highest content of soluble solids and dry matter and the greatest firmness but the lowest acidity and content of nitrites and nitrates. The fruits of the 'Merlot' cultivar had the highest content of L-ascorbic acid, nitrites and nitrates. The pulp colour was largely affected by the maceration temperature. During a warm maceration, the process of pulp darkening accelerated and the red colour saturation increased, whereas cold maceration resulted in the blue colour saturation.
\end{abstract}

Key words: chemical composition, colour $\mathrm{L}^{*} \mathrm{a}^{*} \mathrm{~b}^{*}$, reflectance, Vitis vinifera

\section{INTRODUCTION}

Viticulture is a dynamically developing industry in the world. The growing popularity of the wine-making culture has led to the development of a new branch of tourism - enotourism. Wine enthusiasts travel along wine routes, savouring wine from various regions of the world. There has been a growing interest of wine tourism in Poland as well. More and more vineyards are established, which has been supported by the fact that the climatic conditions have become milder (Chelpiński et al. 2009). However, there is still a risk of frosts and insufficient insolation during the year. Therefore, research is still being conducted, aimed at selecting the most appropriate cultivars and adapting the cultivation conditions to Polish climate (Ochmian et al. 2012a).

Visible symptoms of grape maturation include changes in fruit colour and loss of turgor (softening), brown colouring of pips and lignification of twigs. The ripening process is accompanied by an increase in the $\mathrm{pH}$ and the sugar content (Holler 2005a). Harvesting grapes too early results in a lower amino acid level, which tends to grow considerably at the last maturation stage. Additionally, before fall the leaf nutrients are mobilised and transported to the fruits (Steidl and Renner 2008). Vinification of red wine requires maceration, i.e. fermenting the pulp. This makes possible to extract the largest quantity of dyes from the grapes (Myśliwiec 2006, Soleas et al. 1997) and to make the most distinct wines (Holler 2005a). In the production of red wine, two processes are mainly taken into account: pulp fermentation and pulp heating (Holler 2005b). During maceration dyes, tannins and aromas are extracted from the grape seeds, pulp and skins (Soleas et al. 1997, Vinson et al. 2001). Without this stage, the must would be deprived of the desired red colour, which it owes 
to anthocyanins contained in the fruit skin (Ochmian et al. 2011). Grape maceration takes place in alcohol produced as a result of their fermentation. The maceration time ranges from 2-3 days (if enzymes are used) to 2 weeks. This stage is omitted in white wine production, where the grapes are pressed directly after harvest. Aromatic cultivars are an exception here - in this case a several-hour-long maceration process can be applied (Bosak 2006).

Undoubtedly, temperature is an important factor affecting the effectiveness of maceration. Usually it is aimed to achieve a higher must temperature for the proper development of the inoculated yeast. Depending on the temperature of the fermentation, yeasts produce different side products. At lower temperatures, predominantly ethyl esters are being formed, whereas at higher acetate esters (Garde-Cerdan and Ancin-Azilicueta 2008, Bardi et al. 1997). Cold fermentation is carried out mostly at temperatures below $15{ }^{\circ} \mathrm{C}$. Wines obtained in this way are more subdued, gentle, contain less tannin compounds, and are characterized by a richer bouquet (Morakul et al. 2011).

Warm maceration can be done by heating the pulp up to $40-45^{\circ} \mathrm{C}$ during $12-36$ hours. This makes possible to achieve a deep colour and high tannin content (Casamayor 2008). Cold maceration is a method consisting in keeping the sulphur dioxide-containing pulp at temperatures slightly above $0{ }^{\circ} \mathrm{C}$ and in the presence of $\mathrm{CO}_{2}$ for many days (Holler 2005b). Higher temperatures at the subsequent stage initiate the fermentation process. The result of this treatment can be spectacular as far as the colour is considered, especially for the 'Pinot Noir' cultivar, for which it is usually difficult to obtain the right colour (Casamayor 2008).

The aim of the research presented was to compare the quality of fruits of three grapevine cultivars and to analyse changes of their must during maceration process.

\section{MATERIALS AND METHODS}

The research, focused on three grapevine cultivars: 'Mavrud', 'Pinot Noir' and 'Merlot', was conducted in the years 2010-2011 at the Agricultural University in Plovdiv in the cooperation be- tween the Department of Horticulture of West Pomeranian University of Technology in Szczecin and the Department of Viticulture of the Agricultural University in Plovdiv. Plants were grown at the Agricultural Research Station of the University of Plovdiv in a cinnamon-brown soil with $\mathrm{pH} 7.1$ since 2003. The annual sum of hours with temperatures $>10^{\circ} \mathrm{C}$ was about 3900 , and the average annual precipitation was $515 \mathrm{~mm}$. In both years, the fruits were harvested in the third decade of September.

'Pinot Noir' is a French cultivar from the Burgundy region. The plants are characterized by average growth intensity and fruitfulness. To obtain a higher yield, the shrub must be cut to leave 10-12 buds. The fruits are navy blue and red in colour, small and spherical. The clusters are usually small and compact. This cultivar enjoys great popularity all over the world as it allows obtaining high quality wines. 'Merlot' is a common cultivar with growing popularity all over the world. It is perfect for mixing with other kinds of wines. Shrubs are characterized by high fruit-bearing ability. The fruits have low tannin contents owing to the thin skin and low acidity. This cultivar allows obtaining mild wine with a slightly sweet taste. 'Mavrud' is a Balkan cultivar grown mainly in the central-southern part of Bulgaria, in the Plovdiv area, and is considered the best local red cultivar. It is characterized by low cropping. The fruits are dark and produce extractive tannin wines with a spiced aftertaste. This cultivar is probably related to the Greek 'Mavrodaphne'.

Each year, the chemical composition of the fruits was analysed in three replications, directly after the fruits were fragmented by a crusher. Titratable acidity was determined by titration of a water extract of fruit homogenate with $0.1 \mathrm{~N}$ $\mathrm{NaOH}$ to the end point of $\mathrm{pH} 8.1$ (measured with a multimeter Elmetron CX-732) according to Polish Standard PN-90/A-75101/04, and expressed as citric acid equivalents. L-ascorbic acid, nitrite and nitrate contents were measured with a RQflex 10 reflectometer (Merck). Soluble solids content was determined with a digital refractometer PAL-1 (Atago, Japan). The firmness and puncture resis- 
tance of the skin was measured with a FirmTech 2 apparatus (BioWorks, USA) on 100 randomly selected berries from each replicate. Data were expressed as a gram-force causing fruit surface to bend by $1 \mathrm{~mm}$. Punctures were made using a stamp (pivot) with a diameter of $3 \mathrm{~mm}$. Dry matter of fruit was determined with a gravimetric method (drying an aliquot $\sim 5 \mathrm{~g}$ of fruit tissue at $105{ }^{\circ} \mathrm{C}$ to constant weight), according to Polish Standard PN90/A-75101/03. A hand-held spectrophotometer equipped with photodiode array capturing the range 400-1100 $\mathrm{nm}$ was used for non-destructive measurement of quality parameters (CP Pigment Analyzer PA1101 produced by Control in Applied Physiology GbR., Germany). Spectra collected from CP PA1101 were used for calculating two indices: Normalized Difference Vegetation Index NDVI $=(I 780-I 680) /(I 780+1680)$ and Normalized Anthocyanin Index NAI $=(I 780-$ I570)/(I780+1570) (Zude 2003). Fruit, juice and pulp colour (CIE $\mathrm{L}^{*} \mathrm{a}^{*} \mathrm{~b}^{*}$ ) and reflectance were measured with Konica Minolta CM-700d spectrophotometer. Measurements were taken with the aperture diameter $3 \mathrm{~mm}$; juice and pulp colour was measured in glass cuvettes adapted to the instrument, through a $10^{\circ}$ observer type and D65 illuminant. In order to measure the basic colour of the fruit, natural wax coating was removed mechanically and the same fruits were measured with wax and without wax coating. The must colour was compared after 24 hours, 5 days and 10 days of cold (must temperatures ranging from 7 to $10{ }^{\circ} \mathrm{C}$ ) and warm maceration (must temperatures ranging from 20 to $22{ }^{\circ} \mathrm{C}$ ). The fruits of each cultivar were disinfected before maceration using potassium pyrosulphate. After 24 hours, the pulp was inoculated using wine-making yeast ICV K1W-1116 characterized by a broad range of fermentation temperatures of $5-35^{\circ} \mathrm{C}$.

The results were statistically evaluated by single-factorial analysis of variance (ANOVA) using the Statistica 10 programme (StatSoft 2011). The significance of differences was assessed using Tukey's test at the significance level $\alpha=0.05$.

\section{RESULTS AND DISCUSSION}

Differences between the cultivars in respect of the size and weight of fruit clusters and fruits were found (Tables $1 \& 2$ ). Out of the three cultivars tested, the largest clusters in terms of both their weight and length were recorded in 'Mavrud'. Fruits of this cultivar were the largest and had the lowest firmness and puncture resistance and the lowest acidity among the cultivars analysed. Similar characteristic of 'Mavrud' fruits was reported by Papanikolau et al. (2009). 'Pinot Noir' fruits were characterized by the highest soluble solids and dry matter contents, the highest fruit firmness and puncture resistance as well as the lowest titratable acidity and the lowest content of L-ascorbic acid, nitrites and nitrates. The nitrite content in all the cultivars tested was at a relatively low level.

The highest differences in the measured features of the fruits were found between 'Merlot' and 'Mavrud' cultivars. 'Merlot' fruits were characterized by the highest content of nitrites, nitrates and L-ascorbic acid. In addition, in this cultivar the highest differentiation was found in the fruits firmness; the least firm and the most firm fruits had firmness $69.4 \mathrm{G} \cdot \mathrm{mm}^{-1}$ and over $600 \mathrm{G} \cdot \mathrm{mm}^{-1}$, respectively (Table 2). Pandeliev et al. (2010) found a slightly higher acidity in fruits of the 'Merlot' cultivar, at the level of approx. $0.6 \mathrm{~g}$ in $100 \mathrm{~cm}^{3}$ of must. Acidity of 'Cabernet Sauvignon' fruits grown in California ranged from 0.3 to $0.4 \mathrm{~g}$ (Bergqvist et al. 2001) and in Spain from 0.24 to $0.53 \mathrm{~g}$ in $100 \mathrm{~cm}^{3}$ of must (Ryan and Revilla 2003). In grapevine fruits growing in Australia, the dry matter content ranged from 23 to $39 \%$ (Cozzolino et al. 2008). The cultivars analysed in the work presented were characterized by a lower content of L-ascorbic acid, compared to the fruits of 'Regent' cultivar, which contained from 8.6 to $13 \mathrm{mg}$ of L-ascorbic acid in $100 \mathrm{~g}$ of fruits. The fruits of 'Pinot Gris', which is considered to be a mutation of 'Pinot Noir', had similar L-ascorbic acid content $-5.5 \mathrm{mg}$ in $100 \mathrm{~g}$ of fruits (Ochmian et al. 2010; Chełpiński et al. 2009). It needs to be emphasized that under Polish climate, the most desirable feature for a winemaker is the highest soluble solids content in the fruits. 
Table 1. Grapevine yield parameters (mean values from seasons 2010 and 2011)

\begin{tabular}{|c|c|c|c|c|c|c|}
\hline \multirow[t]{2}{*}{ Tested feature } & \multicolumn{6}{|c|}{ Cultivar } \\
\hline & \multicolumn{2}{|c|}{ Mavrud } & \multicolumn{2}{|c|}{ Pinot Noir } & \multicolumn{2}{|c|}{ Merlot } \\
\hline Mass of cluster (g) & \multicolumn{2}{|c|}{$497 b^{*}$} & \multicolumn{2}{|c|}{$171 \mathrm{a}$} & \multicolumn{2}{|c|}{$160 \mathrm{a}$} \\
\hline Length of cluster (cm) & \multicolumn{2}{|c|}{$22.0 \mathrm{~b}$} & \multicolumn{2}{|c|}{$15.0 \mathrm{a}$} & \multicolumn{2}{|c|}{$16.0 \mathrm{a}$} \\
\hline Weight of 100 fruits $(\mathrm{g})$ & \multicolumn{2}{|c|}{$171 \mathrm{~b}$} & \multicolumn{2}{|c|}{$159 \mathrm{~b}$} & \multicolumn{2}{|c|}{$131 \mathrm{a}$} \\
\hline Dry matter content (\%) & \multicolumn{2}{|c|}{$27.5 \mathrm{a}$} & \multicolumn{2}{|c|}{$28.8 \mathrm{~b}$} & \multicolumn{2}{|c|}{$28.1 \mathrm{ab}$} \\
\hline Soluble solids content $(\%)$ & \multicolumn{2}{|c|}{$24.3 \mathrm{~b}$} & \multicolumn{2}{|c|}{$25.7 \mathrm{c}$} & \multicolumn{2}{|c|}{$23.1 \mathrm{a}$} \\
\hline $\begin{array}{l}\text { L-ascorbic acid content } \\
\left(\mathrm{mg} \cdot 1000 \mathrm{~g}^{-1}\right)\end{array}$ & \multicolumn{2}{|c|}{$42.9 \mathrm{ab}$} & \multicolumn{2}{|c|}{$29.7 \mathrm{a}$} & \multicolumn{2}{|c|}{$56.1 \mathrm{~b}$} \\
\hline $\mathrm{NO}_{3}$ content $\left(\mathrm{mg} \cdot \mathrm{kg}^{-1}\right)$ & \multicolumn{2}{|c|}{$42.9 \mathrm{~b}$} & \multicolumn{2}{|c|}{$20.9 \mathrm{a}$} & \multicolumn{2}{|c|}{$49.5 \mathrm{~b}$} \\
\hline $\mathrm{NO}_{2}$ content $\left(\mathrm{mg} \cdot \mathrm{kg}^{-1}\right)$ & \multicolumn{2}{|c|}{$4.51 \mathrm{~b}$} & \multicolumn{2}{|c|}{$1.54 \mathrm{a}$} & \multicolumn{2}{|c|}{$4.95 \mathrm{~b}$} \\
\hline $\begin{array}{l}\text { Titratable acidity } \\
\left(\mathrm{g} \cdot \text { citric acid } 100 \mathrm{~g}^{-1}\right)\end{array}$ & \multicolumn{2}{|c|}{$0.77 \mathrm{c}$} & \multicolumn{2}{|c|}{$0.33 \mathrm{a}$} & \multicolumn{2}{|c|}{$0.48 \mathrm{~b}$} \\
\hline \multirow[b]{2}{*}{ Colour CIE L*a*b* } & \multicolumn{6}{|c|}{ Fruits } \\
\hline & $\begin{array}{c}\text { with wax } \\
\text { coating }\end{array}$ & $\begin{array}{c}\text { without wax } \\
\text { coating }\end{array}$ & $\begin{array}{c}\text { with wax } \\
\text { coating }\end{array}$ & $\begin{array}{c}\text { without wax } \\
\text { coating }\end{array}$ & $\begin{array}{c}\text { with wax } \\
\text { coating }\end{array}$ & $\begin{array}{c}\text { without wax } \\
\text { coating }\end{array}$ \\
\hline $\mathrm{L}^{*}$ & $40.81 \mathrm{a}$ & $27.26 \mathrm{~A}$ & $34.53 \mathrm{~b}$ & $26.14 \mathrm{~A}$ & $33.19 \mathrm{~b}$ & $23.94 \mathrm{~B}$ \\
\hline$a^{*}$ & $-1.14 b$ & $0.10 \mathrm{~A}$ & $-0.23 \mathrm{a}$ & $2.56 \mathrm{~B}$ & $-0.74 a b$ & $3.51 \mathrm{~B}$ \\
\hline \multirow[t]{2}{*}{$b^{*}$} & $-7.77 \mathrm{~b}$ & $-9.24 \mathrm{C}$ & $-1.74 \mathrm{a}$ & $-6.47 \mathrm{~B}$ & $-2.23 \mathrm{a}$ & $-3.28 \mathrm{~A}$ \\
\hline & \multicolumn{6}{|c|}{ Index } \\
\hline NDVI & & $6 \mathrm{~b}$ & & $1 \mathrm{a}$ & & $35 \mathrm{a}$ \\
\hline NAI & & $1 \mathrm{c}$ & & $2 \mathrm{~b}$ & & $30 \mathrm{a}$ \\
\hline
\end{tabular}

*Means marked with the same letter do not differ significantly at $\mathrm{P}=0.05$ according to Tukey's test. Small letters marked significant differences in fruit colour (CIE L*a*b*) with natural wax coating and capital letters fruit colour without wax coating.

Table 2. Fruit diameter, firmness, and puncture resistance of the skin of the grapevine cultivars under analysis (mean values from the seasons 2010 and 2011)

\begin{tabular}{llccc}
\hline Tested feature & Cultivar & Mean & Min. & Max. \\
\hline Diameter & Mavrud & $16.4 \mathrm{~b}$ & 13.7 & 18.6 \\
$(\mathrm{~mm})$ & Pinot Noir & $15.7 \mathrm{ab}$ & 13.2 & 17.7 \\
& Merlot & $14.8 \mathrm{a}$ & 12.1 & 23.3 \\
\hline Firmness & Mavrud & $190 \mathrm{a}$ & 86.0 & 262 \\
$\left(\mathrm{G} \cdot \mathrm{mm}^{-1}\right)$ & Pinot Noir & $290 \mathrm{c}$ & 148.7 & 377 \\
& Merlot & $249 \mathrm{~b}$ & 69.4 & 605 \\
\hline Force for & Mavrud & $91 \mathrm{a}$ & 54.8 & 119 \\
puncture of & Pinot Noir & $149 \mathrm{~b}$ & 101.3 & 213 \\
the skin & & $131 \mathrm{~b}$ & 51.8 & 222 \\
$\left(\mathrm{G} \cdot \mathrm{mm}^{-1}\right)$ & Merlot & & & \\
\hline
\end{tabular}

*Means marked with the same letter do not differ significantly at $\mathrm{P}=0.05$ according to Tukey's test

An analysis of the results presented in Table 1 reveals that fruits of all three cultivars were darker without natural wax coating. The 'Merlot' fruits proved to be the darkest, with and without wax coating. This may make the visual assessment of fruit ripeness more difficult. Similar dependence was observed for fruits from other species, especially these with the dark basic skin colour, e.g. highbush blueberry and blue honeysuckle (publications in press). In all the cultivars tested, the $a^{*}$ parameter showed a high intensity of the green colour component of fruits with natural wax coating whereas fruits without natural wax coating had a higher intensity of red colour component. The largest share of the green colour component was found in the 'Mavrud' fruits. The blue colour component, marked with the $b^{*}$ parameter, for fruits without natural wax coating was also the highest for the fruits of 'Mavrud' cultivar.

The analysis of reflectance (Fig. 1) revealed its higher differentiation in fruits without wax coating, especially in the frequency range (wavebands) 
from 380 to $520 \mathrm{~nm}$ and 650 to $740 \mathrm{~nm}$. The highest reflectance for fruits without natural wax coating in the first waveband was found for the 'Mavrud' cultivar fruits at $440 \mathrm{~nm}$ (34.9\%), for 'Pinot Noir' and 'Merlot' at $450 \mathrm{~nm}$ (respectively $31.7 \%$ and $24.2 \%$ ). In this waveband 'Mavrud' fruits were characterized by the highest reflectance (which is reflected in the lowest value of the $b^{*}$ parameter). In the second wavebands there were no peaks - the reflectance steadily increased from ca. $650 \mathrm{~nm}$ and reached stable level. In this range the highest value of reflectance was observed for 'Merlot' fruits (which is reflected by the highest value of the $a^{*}$ parameter), then 'Pinot Noir' and the lowest for 'Mavrud'. The fruits of 'Mavrud' cultivar were characterized by the highest NAI and NDVI indices. The lowest NAI index was found for 'Merlot' fruits.

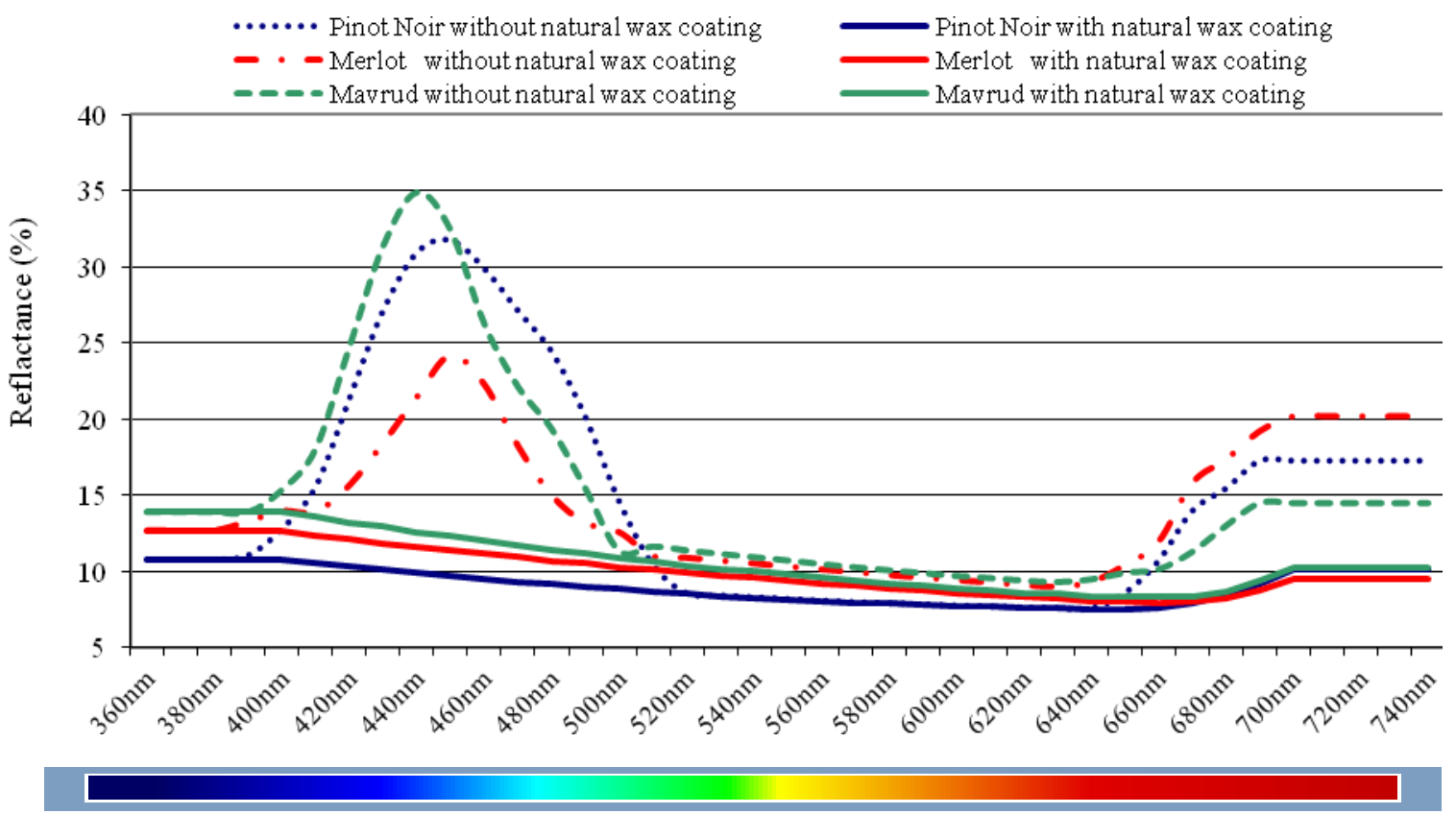

Figure 1. Reflectance of the fruits under analysis - with and without natural wax coating

Fruit colour of grapevine and blue honeysuckle species is perceived by human eye as "similar" or "close", however they differ significantly in $a^{*}$ and $b^{*}$ parameters (Ochmian et al. 2012b). During the maceration process, regardless of the cultivar, the darkening of the must was observed (the $\mathrm{L}^{*}$ parameter decreased) (Fig. 2). This process occurred more quickly (especially on the first day) during warm maceration. These results may suggest better leaching of the dyes from the skin to the juice at higher temperatures. Similar observations were made for other grape cultivars (Ochmian et al. 2011). The amount of the blue dye, regardless of the cultivar, increased during the maceration process (an increase in the negative values of the $\mathrm{b}^{*}$ parameter). Initially, the increase was stronger during warm maceration (the first day) but for cold maceration increase was considerably stronger later on. Similar situation was observed with red colour component (the $a^{*}$ parameter) in the 'Mavrud' cultivar. It was characterized by a constant increase during the subsequent days, which was higher during the cold maceration. For 'Pinot Noir' cultivar, an increase in the red colour component intensity was observed only on the first day of maceration, which subsequently showed a similar level (higher values for warm maceration). An increase in the red colour component intensity with time was observed for the 'Merlot' cultivar, but only during the warm maceration. During the cold maceration, the red colour component intensity remained at a similar level throughout the maceration process. 


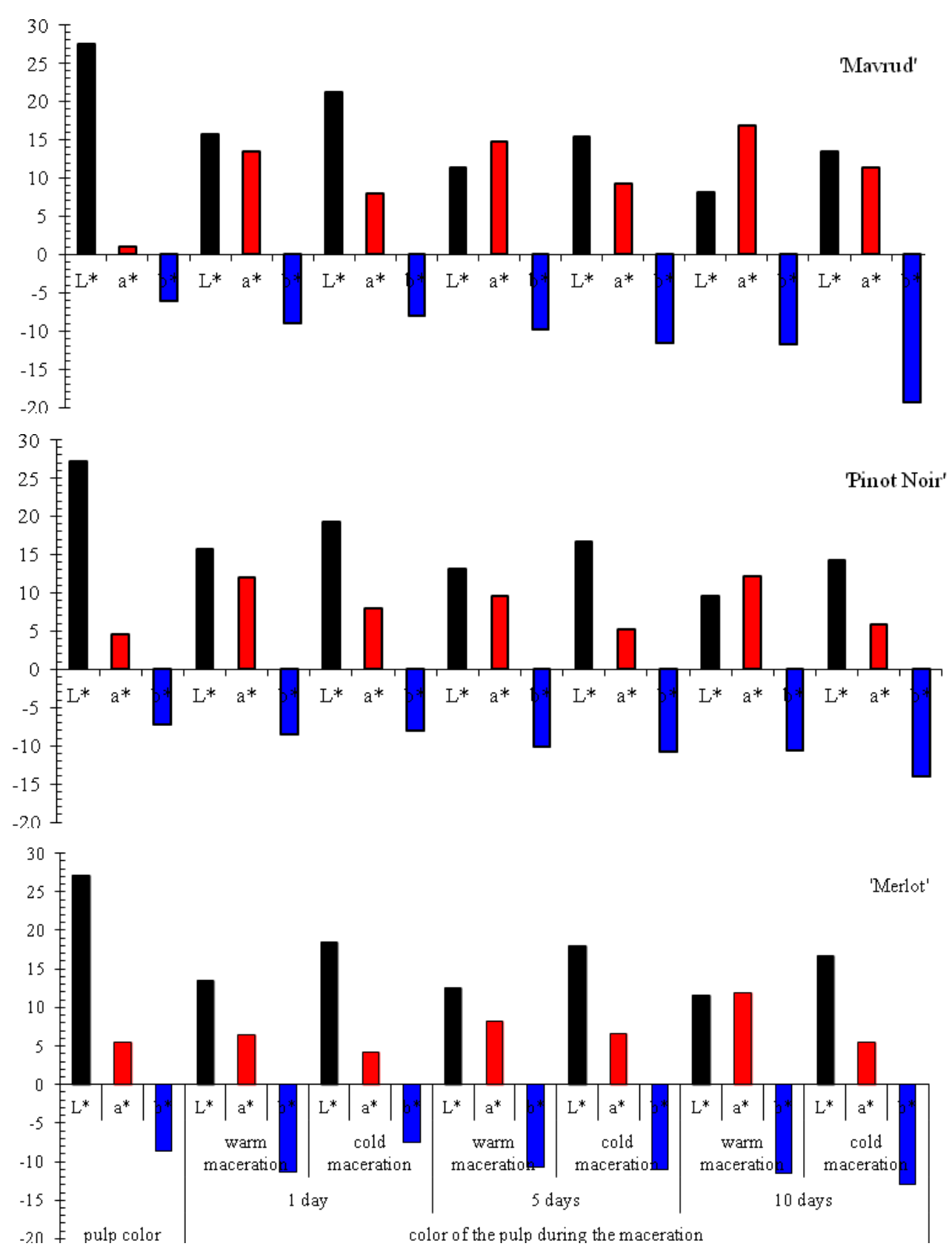

Figure 2. The colour of the pulp depending on the temperature and the maceration period

\section{CONCLUSIONS}

1. 'Mavrud' cultivar was characterized by the largest clusters and fruits of the three cultivars tested, but the fruits were the least firm and had the highest acidity.

2. The fruits of 'Pinot Noir' were characterized by the highest soluble solids and dry matter contents, the greatest firmness and the lowest acidity, and the content of $\mathrm{NO}_{2}$ and $\mathrm{NO}_{3}$.
3. The 'Merlot' fruits had the largest content of Lascorbic acid, nitrites and nitrates.

4. For precise determination of the skin colour, it is necessary to remove natural wax coating from the fruits, which resulted in an increase in the differentiation of the reflectance and the $a^{*}$ and $b^{*}$ colour parameters of the fruits.

5. Differentiation of the maceration temperatures affected the must-darkening rate and the change in its colour. Warm maceration accelerated the 
must-darkening process and resulted in higher saturation of the must with the red colour (parameter $\mathrm{a}^{*}$ ) than with the blue colour (parameter $\left.\mathrm{b}^{*}\right)$, which takes place during cold maceration.

\section{Acknowledgements}

This work was supported by the Operational Programme for objective 3 "European territorial cooperation cross-border cooperation" between the federal states Mecklenburg-Vorpommern/Brandenburg and the Republic of Poland (Vojvodship Zachodniopomorskie) 2007-2012 - known as "INTERREG IV A", under grant INT-08-0016.

\section{REFERENCE}

Bardi E., Koutinas A.A., Psarianos C., Kanellaki M. 1997. Volatile by-products formed in lowtemperature wine-making using immobilized yeast cells. Biochem. 32(7): 579-584.

Bergqvist J., Dokoozlian N., Ebisuda N. 2001. Sunlight exposure and temperature effects on berry growth and composition of Cabernet Sauvignon and Grenache in the Central San Joaquin Valley of California. Am. J. Enol. Vitic. 52: 1-7.

Bosak W. 2006. Winorośl i wino w małym gospodarstwie w Małopolsce. Małopolska Agencja Rozwoju Regionalnego S.A., Kraków, 67p.

Casamayor P. 2008. Wino - 80 najważniejszych pytań i odpowiedzi. Hachette Livre Polska sp. z o.o. Warszawa, pp. 44-45, 66-67.

Chełpiński P., Gembara J., Ochmian I., Grajkowski J. 2009. Uprawa winorośli w okolicach Szczecina. Materiały Seminaryjne III Seminarium Winiarskie. 23.01.2009. Instytut Zarządzania i Inżynierii Rolnej Państwowej Wyższej Szkoły Zawodowej w Sulechowie, Sulechów, pp. 64-65.

Cozzolino D., Cynkar W.U., Dambergs R.G., Mercurio M.D., Smith P.A. 2008. Measurement of condensed tannins and dry matter in red grape homogenates using near infrared spectroscopy and partial least squares J. Agric. Food Chem. 56(17): 7631-7636.

Garde-Cerdán T., Ancín-Azpilicueta C. 2008. Effect of the addition of different quantities of amino acids to nitrogen-deficient must on the formation of esters, alcohols, and acids during wine alcoholic fermentation. Food Sci. Techn. 41(3): 501-510.

Holler R. 2005a. Produkcja wina. Część I. Przetwarzanie winogron, moszczu, fermentacja alkoholowa, ochrona przed utlenianiem, klarowanie, zbiorniki na wino. Szkoła Winiarska Silberberg. Leibnitz, pp. 5-6, 34-35, 37-38.

Holler R., 2005b. Produkcja wina. Część II. Fermentacja malolaktyczna, produkcja wina czerwonego, stabilizacja, przygotowanie butelek do wina. Szkoła Winiarska Silberberg, Leibnitz, pp. 13, 1718.

Morakul S., Mouret J.R., Nicolle P., Trelea I.C., Sablayrolles J.M., Athes V. 2011. Modelling of the gasliquid partitioning of aroma compounds during wine alcoholic fermentation and prediction of aroma losses. Biochem. 46(5): 1125-1131.

Myśliwiec R. 2006. Winorośl w ogrodzie. PWRiL, Warszawa, pp. 30, 110, 112.

Ochmian I., Chełpiński P., Gembara J. 2010. Mikoryza w uprawie winorośli. IV Konferencja Winiarska. Nowości w uprawie winorośli i produkcji win. Materiały konferencyjne Instytut Zarządzania i Inżynierii Rolnej Państwowej Wyższej Szkoły Zawodowej w Sulechowie, 22.01.2010, Sulechów, pp. 81-85.

Ochmian I., Chełpiński P., Grajkowski J., Kruszewska A., Rozwarski R. 2011. Wpływ sposobu maceracji moszczu na barwę wina. W: Prace Instytutu Zarządzania i Inżynierii Rolnej w Kalsku i Państwowej Wyższej Szkoły Zawodowej w Sulechowie. V Międzynarodowa Konferencja Winiarska. Materiały konferencyjne. 25.03.2011, Kalsk, pp. 93-98.

Ochmian I., Chełpiński P., Rozwarski R., Strzelecki R., Pantecki P., Angelov L., Stalev B. 2012a. Jakość owoców dwóch odmian winorośli oraz wpływ sposobu ich maceracji na barwę moszczu. Folia Pomer. Univ. Technol. Stetin. Agric., Aliment., Pisc. Zootech. 295(22): 35-42.

Ochmian I., 2012b. The impact of foliar application of calcium fertilizers on the quality of highbush blueberry fruits belonging to the 'Duke' cultivar. Not. Bot. Horti. Agrobot. 40(2): 163-169.

Pandeliev S., Angelov L., Stalev B., Papanikolaou M. 2010. Szanse ekologicznej uprawy winorośli w południowych winiarskich regionach Bułgarii (wersja oryginalna) W: Prace Instytutu Zarządzania i Inżynierii Rolnej Państwowej Wyższej Szkoły Zawodowej w Sulechowie. IV Konferencja Winiarska. Nowości w uprawie winorośli i produkcji win. Materiały konferencyjne, 22.01.2010, Sulechów. pp. 99-110.

Papanikolau M., Atanasova D., Pandeliev S., Fartsov K. 2009. Determination of the possibilities for biological production of grapes of 'Mavrud' cultivar, 
grown in the region of Novi Izvor, municipality of Assenovgrad. Bulgar. J. Agric. Sci. 15(1): 1-8.

Ryan J-M., Revilla E. 2003. Anthocyanin composition of Cabernet Sauvignon and Tempranillo grapes at different stages of ripening. J. Agric. Food Chem. 51: 3372-3378.

Soleas G.J., Diamandis E.P., Goldberg D.M. 1997. Wine as a biological fluid: history, production and role in disease prevention. J. Clin. Lab. Anal. 11: 287-313.

Steidl R., Renner W. 2008. Problemy fermentacji win. Pro Libris - WiMBP im. C. Norwida w Zielonej Górze. Zielona Góra, pp. 11, 16, 24, 36-37, 62-63.
StatSoft Inc. 2011. STATISTICA (data analysis software system), version 10.0. www.statsoft.com.

Zude M. 2003. Comparison of indices and multivariate models to non-destructively predict the fruit chlorophyll by means of visible spectrometry in apple fruit. Anal. Chim. Acta 481: 119-126.

Vinson J.A., Su X., Zubik L., Bose P. 2001. Phenol antioxidant quantity and quality in food. J. Agric. Food Chem. 49: 5315-5321. 